\title{
植物成長調節剤がブドゥサンショウの秋梢抑制に及ぼす影響
}

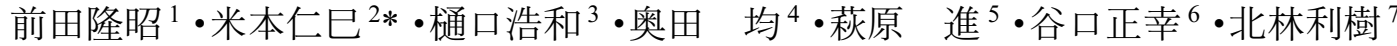 \\ 1 和歌山県就農支援センター 644-0024 和歌山県御坊市塩屋町 \\ 2 独立行政法人 国際農林水産業研究センター 熱帯・島嶼研究拠点 907-0002 沖縄県石垣市真栄里川良原 \\ 3 京都大学大学院農学研究科 606-8502 京都市左京区北白川 \\ ${ }^{4}$ 三重大学大学院生物資源学研究科附属紀伊黒潮生命地域フィールドサイエンスセンター付帯施設農場 $514-2221$ 三重県津市 \\ 高野尾町 \\ 5 和歌山県農林水産総合技術センター＼cjkstart林業試験場６49-2103＼cjkstart和歌山県西军婁郡上富田町 \\ 6 和歌山県ふるさと定住センター 649-4222 和歌山県東牟婁郡古座川町 \\ 7 ありだ農業協同組合６43-0521＼cjkstart和歌山県有田郡有田川町
}

\section{Effect of Plant Growth Regulator on Suppression of Fall Sprouting in Japanese Pepper (Zanthoxylum piperitum (L.) DC. f. inerme Makino)}

\author{
Takaaki Maeda $^{1}$, Yoshimi Yonemoto ${ }^{2 *}$, Hirokazu Higuchi $^{3}$, Hitoshi Okuda $^{4}$, \\ Susumu Hagiwara ${ }^{5}$, Masayuki Taniguchi ${ }^{6}$ and Toshiki Kitabayashi ${ }^{7}$ \\ ${ }^{1}$ Wakayama Prefecture Support Center for New Farmers, Shioya, Gobou, Wakayama 644-0024 \\ ${ }^{2}$ Japan International Research Center for Agricultural Sciences, Tropical Agriculture Research Front, Maezato, Kawarabaru, Ishigaki, Okinawa 907-0002 \\ ${ }^{3}$ Graduate School of Agriculture, Kyoto University, Kitashirakawa, Sakyo, Kyoto 606-8502 \\ ${ }^{4}$ Field Science Center of Kii-Kuroshio Life Area, Faculty of Bioresources, Mie University, Takanoo, Tsu, Mie 514-2221 \\ ${ }^{5}$ Wakayama Prefecture Experiment Station for Forestry, Kamitonda, Nishimuro, Wakayama 649-2103 \\ ${ }^{6}$ Wakayama Prefecture Home Country Settlement Center, Kozagawa, Higashimuro, Wakayama 649-4222 \\ ${ }^{7}$ Arida Agricultural Cooperative, Aridagawa, Arida, Wakayama 643-0521
}

\begin{abstract}
A method of suppressing sprouting in Budousanshou (Zanthoxylum piperitum (L.) DC. f. inerme Makino) due to early defoliation in the fall by diseases and pests was investigated. We used three plant growth regulators naphthaleneacetic acid (NAA), ethychlozete and maleic hydrazide (MH) to suppress sprouting. Ethychlozete has been used to suppress sprouting in Satsuma mandarin (Citrus unshiu Marcow.) in green house cultivation. Budousanshou belongs to the same family as Satsuma mandarin. NAA and MH have been tested with other citrus species. Nine days after the application of the plant growth regulators, trees were hand-defoliated and stems were sampled for bud sprouting. Sprouting days and percentages in the experimental field were investigated by the stem cutting method using sampled stems. Trees treated with 200 ppm NAA exhibited maximum number of days to sprouting with sprouting being suppressed for approximately 30 days. In the stem cutting method sprouting stem percentage was $0 \%$. In the experimental field sprouting percentage was also low with $9 \%$. Our study suggests that treatment with $200 \mathrm{ppm}$ NAA is highly effective for suppressing fall sprouting, and is of practical importance in fruit production.
\end{abstract}

Key Words : days to bud sprouting, ethychlozate, maleic hydrazide (MH), naphthaleneacetic acid (NAA), sprouting percentage キーワード：エチクロゼート, 発芽所要日数, 発芽率, MH, NAA

\section{緒 言 \\ 和歌山県のブドウサンショウ (Zanthoxylum piperitum (L.) DC. f. inerme Makino）の収穫期は 5〜8月と長期間にわた}

2007 年 8 月 27 日 受付. 2007 年 12 月 7 日 受理. 本報告の概要は園芸学会平成 19 年度秋季大会で発表した。

* Corresponding author. E-mail: yonetrop@affrc.go.jp
るために，収穫作業への労働配分率が高い、さらに，収穫 終了園と未収穫園が混在するために既収穫園への収穫後の 薬剂防除による未収穫園への農薬飛散が懸念されるため に，病害虫防除が困難である，そのため，栽培現場では秋 季の病害虫被害による早期落葉後の不時発芽が大きな問題 となっている. 従って, 栽培現場では収穫終了後の 8 月下 旬以降の不時発芽対策が必要となっている.

和歌山県に打けるブドウサンショウの休眠期は通常 11 月 
下旬から翌年の 1 月下旬であり（前田ら，2007），落葉期は 11 月下旬であるが，それ以前でも病害虫被害により落葉す ると新梢が発生し, 秋季にその先端に花房が着生する（前田 ら，2005）。その結果, 翌年の収量が減少する. 従って, 収 量を減少させないためには, 休眠期に至るまで秋梢の発生を 抑制する必要があるが，その方法は明らかではなかった。

ブドウサンショウと同じミカン科のウンシュウミカン （Citrus unshiu Marcow.）の夏枝母枝型八ウス栽培で, 収穫 後の剪定により発生した夏枝を結果母枝として利用する場 合，夏枝に再発芽が久られると着花性が著しく低下寸るた め, エチクロゼートによる発芽抑制が行われている（廣瀬, 2003）。また，1-ナフタレン酶酸（NAA）打よびマレイン 酸ヒドラジド（MH）にもカンキッ類（Citrus spp.）の発芽 抑制効果が認められている（河瀬ら，1983; Nauer・Boswell, 1978; Phillips・Tucker, 1974).

そこで, 本研究ではブドウサンショウの秋梢の発生を抑 制する目的で，上記の植物成長調節剤エチクロゼート， $\mathrm{NAA}$ 㧊よび MH の 3 剂の散布を商業園で行い, 秋梢の発 生抑制効果を評価し，その実用可能性を検討した。

\section{材料および方法}

和歌山県有田川町の標高 $400 \mathrm{~m}$ にある商業園に栽植され ているフユザンショウ (Z. alatum Roxb. var. planispinum Rehd. et Wils.）台に接ぎ木された 2 年生ブドウサンショウ 35 樹を 用いた。供試薬剤には, $\mathrm{MH}$ の 6,667 ppm および 4,000 ppm 液, NAA の $200 \mathrm{ppm}$ 抢よび $143 \mathrm{ppm}$ 液, フィガロン乳剤 （エチクロゼートの含有率 20\%）の 1,000 倍（エチクロゼー

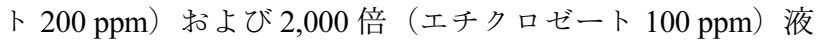
を用いた. NAA はエタノールを数滴加用した後希釈した. 上記処理区に，対照区として水の久の散布区を加光た 7 処 理区を設定し，樹別 7 処理 5 反復で試験を行った.

2006 年 8 月 25 日に $10 \mathrm{~L}$ 容量の肩掛け式噴霧器を用い, 各処理区とも薬剂が滴り落ちる程度に散布した。散布 9 日 後の 2006 年 9 月 3 日に各処理区の 35 樹全てを人為的に全 摘葉した.

\section{試験 1．枝挿し法による秋梢抑制効果の検定}

2006 年 9 月 3 日の全摘葉後, 全 7 処理区の各樹から $15 \mathrm{~cm}$ 程度の中庸な長さの 1 枝を採取した．採取した枝は先端の 5 芽程度を残して, 約 $12 \mathrm{~cm}$ の長さで水切りし, 直ちに生 け花用の発泡フェノール樹脂製保水材オアシス（松村アク

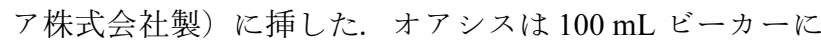
入れ, 事前に水道水を含ませて扔いた. 全 7 処理区から各々 採取した 5 枝ずつを同一ビーカーに插し，90\%以上の湿度 を維持するため, 計 7 個のビーカーを各々 $0.04 \mathrm{~mm}$ 厚のポ リエチレン製袋に密封し, 人工気象器（日本医化器械製作 所製，LH-200-RDCT，照度：7,000 lx）に入れた. 人工気象 器は気温 $25^{\circ} \mathrm{C}$ で維持し, 7 時から 17 時までの 10 時間を明 期, 17 時から翌日 7 時までの 14 時間を暗期に設定した。 そ の後, 1 本の插し枝中いずれかの芽が $3 \mathrm{~mm}$ の長さに成長 した枝を発芽枝, またその日までに要した日数を発芽所要 日数とみなし，いずれも 5 枝の平均值を求め，それぞれ発 芽率揖よび平均発芽所要日数とした.

\section{試験 2. 試験戋場での秋梢抑制効果の検定}

2006 年 9 月 3 日の全摘葉後, 1 樹から無作為に 10 枝を選 び, 各処理区計 50 枝ずつを調査枝とし，発芽所要日数を調 查した，調査基準は試験 1 と同じであった。試験围場で発 芽伸長がみられなくなった 2006 年 11 月 5 日に，各処理区 5 樹から各樹で最も伸長した秋梢を 3 枝ずつ，各処理区計 15 枝を選んでその秋梢長を測定した。2006 年 11 月 5 日に 各処理区 5 樹ずつの主幹部を除く枝の全節を観察し，長さ が $3 \mathrm{~mm}$ 以上となった芽を発芽とみなし，個体ごとの発芽 率を求めた。

\section{結果および考察}

\section{試験 1. 枝挿し法による秋梢抑制効果の検定}

発芽枝率は, MH6,667 ppm, MH4,000 ppm，エチクロゼー ト $200 \mathrm{ppm}$ ，エチクロゼート $100 \mathrm{ppm}$ 预よび対照区ではす べて 100\%であった（第1図）。一方，NAA200 ppm 区では $0 \%$, NAA143 ppm 区では 20\%であった. 発芽所要日数は, MH6,667 ppm, MH4,000 ppm, エチクロゼート $200 \mathrm{ppm}$ ，エ チクロゼート $100 \mathrm{ppm}$ 预よび対照区では 10 日前後であっ

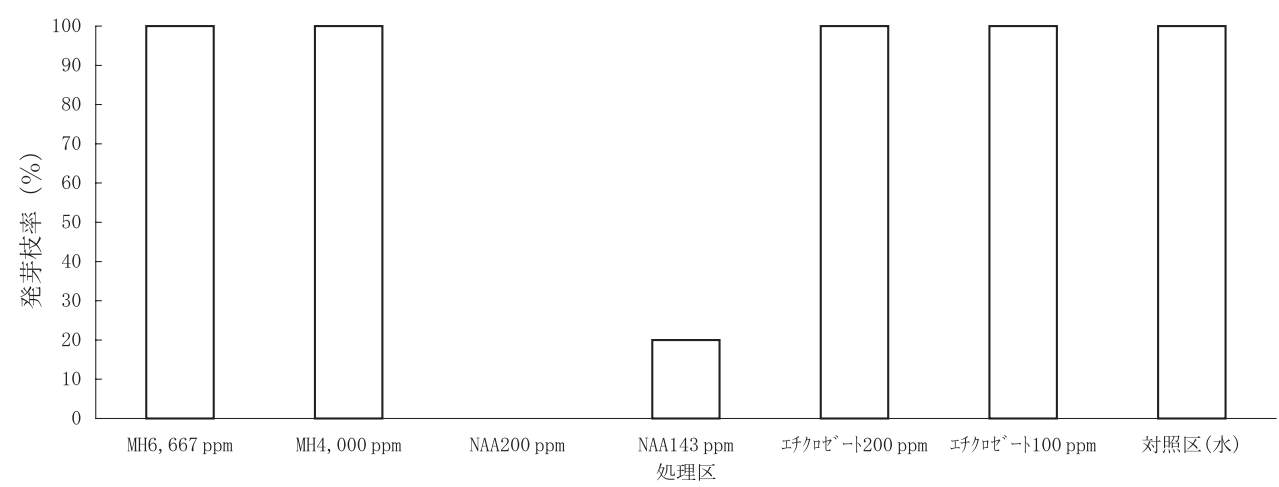

第 1 図 植物成長調節剤散布 9 日後に採取したブドウサンショウの枝挿し法による発芽枝率 


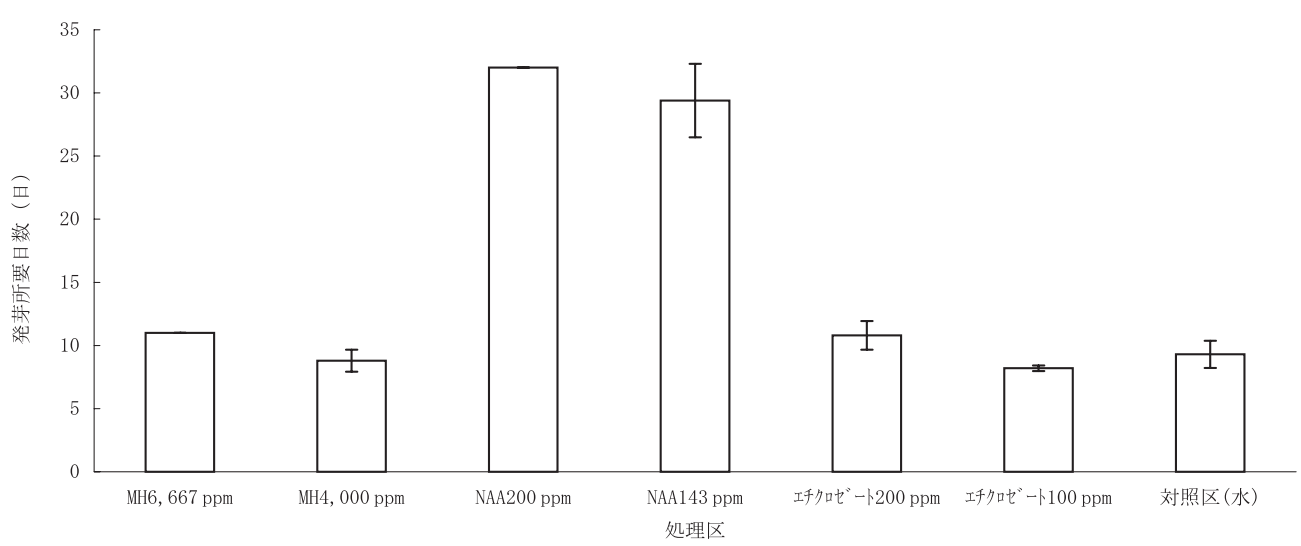

第 2 図 植物成長調節剂散布 9 日後に採取したブドウサンショウの枝插し法による発芽所要日数 図中の縦棒は標準誤差（n=5）を示す

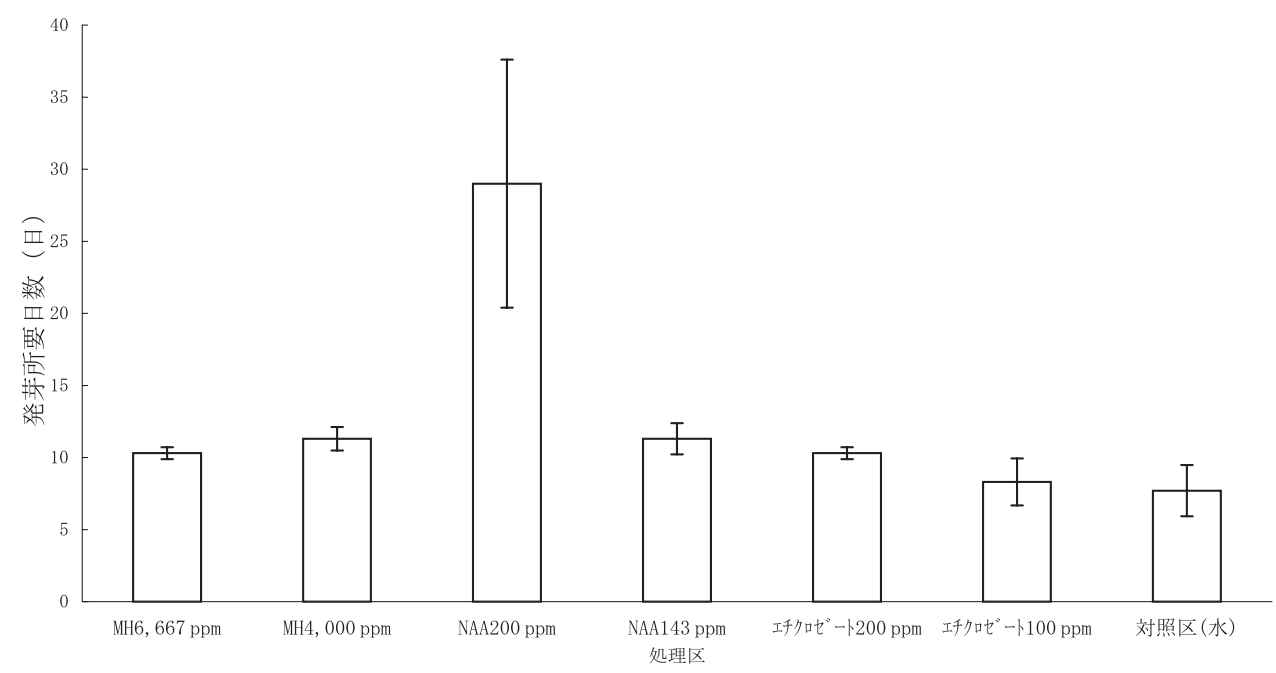

第 3 図 植物成長調節剂散布によるブドウサンショウの発芽所要日数 図中の縦棒は標準誤差（n=50）を示す

たのに対し，NAA143 ppm 区では29日，NAA200 ppm 区で は32 日であった (第 2 図). NAA200 ppm 区は，枝挿し後 32 日目まで発芽がみられず, 芽も発芽しだす様子も又られ なかった. したがって，他の処理区と比較しても差がみら れたため，32 日目で試験を中止し，NAA200 ppm 区の発芽 所要日数は 32 日とした. 以上の枝挿し法の結果から NAA200 ppm 区がブドウサンショウの秋梢抑制に最も効果 的であると考えられた。

\section{試験 2. 試験圃場での秋梢抑制効果の検定}

固場での発芽所要日数は, NAA200 ppm 区では29日で あった（第 3 図）が, その他の処理では摘葉後 10 日前後で あった。

NAA に発芽抑制の効果があることは，アボカド，レモン などの果樹で知られている (Boswellら, 1976; Phillips・Tucker, 1974). 本研究でも NAA200 ppm 液を散布することで，ブド ウサンショウの秋梢の発芽を抑制することができた.

発芽率は, NAA200 ppm 区が 9\%と最低く, 次いでエ チクロゼート 200 ppm 区 < NAA143 ppm 区の順であった.
一方，MH6,667 ppm 区と MH4,000 ppm 区ではそれぞれ 43

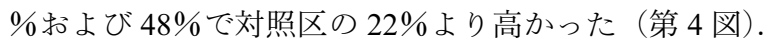

MHを処理した両区では節位にかかわらず $5 \mathrm{~cm}$ 前後の短 い秋梢が発生した。これに対し, NAA200 ppm 区では $10 \mathrm{~cm}$ 程度の, エチクロゼート散布区および対照区では20～ $30 \mathrm{~cm}$ の秋梢が，枝の先端付近から数本発生した（第 5, 6 図）. このよらに，NAA200 ppm 区では枝の先端付近の芽だけが $10 \mathrm{~cm}$ 程度伸長したが, それ以外の芽は発芽しなかった. 以 上の結果から, 固場レベルでも NAA200 ppm 水溶液の散布 処理が，ブドウサンショウの秋梢の発芽抑制に有効である ことがわかった．また，翌年の収量については各処理区と も秋梢が発生したため, 減収することが考えられるが, そ の点については今後の課題である.

山下・濱口（2002）は，八ウスミカンに対するエチクロ ゼートの 2 回処理により秋梢の発生を完全に抑えることが できたと報告している．ブドウサンショウでも，散布濃度 と回数の最適な組み合わせによって，より確実な秋梢の発 生抑制効果が得られるか子知れない. 


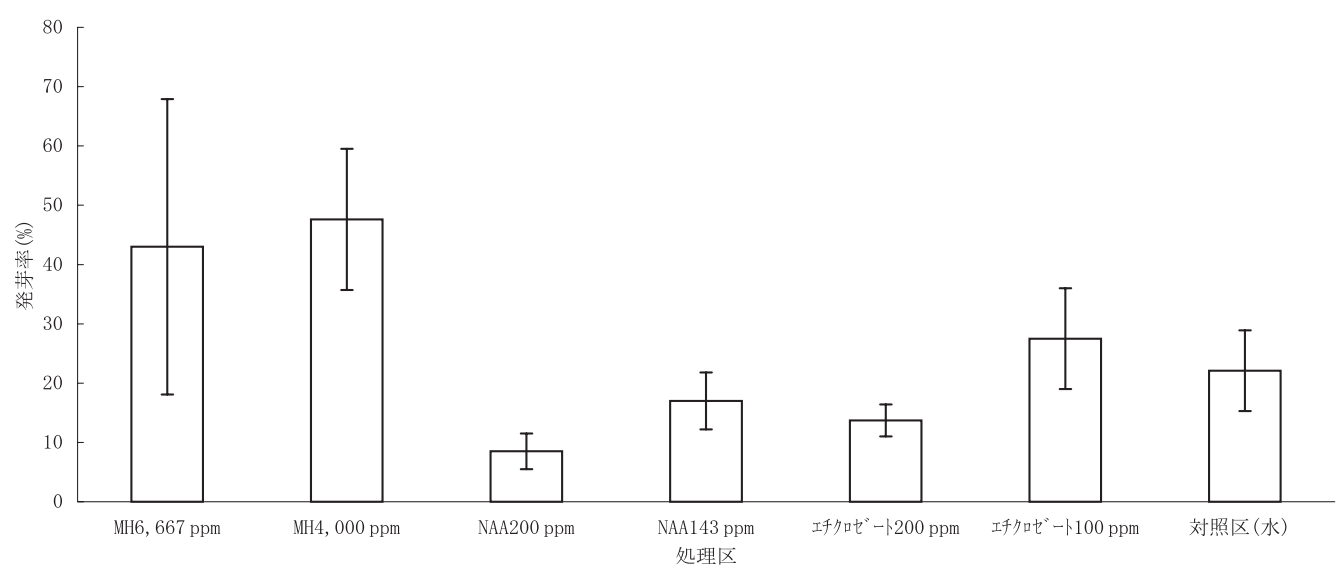

第 4 図 ブドウサンショウ栽培圃場で 9 月 3 日の全摘葉後の発芽率 図中の縦棒は標準誤差（n=5）を示す

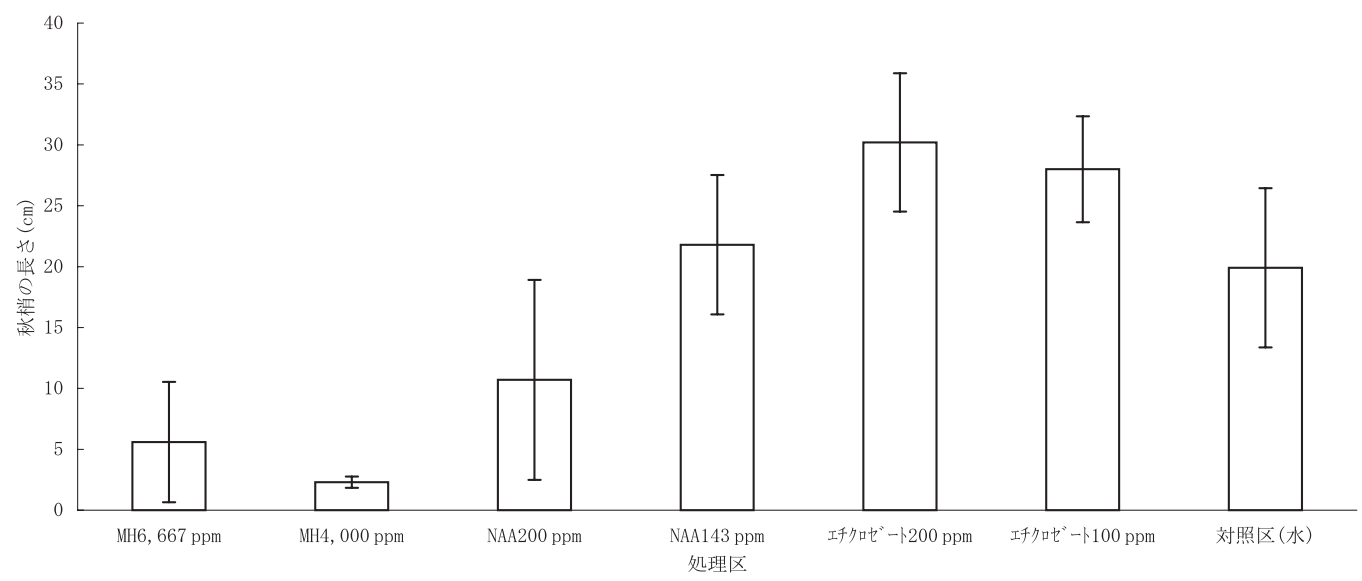

第 5 図 ブドウサンショウ栽培圃場で 9 月 3 日の全摘葉後に発生した秋梢の長さ 図中の縦棒は標準誤差（n=15）を示す

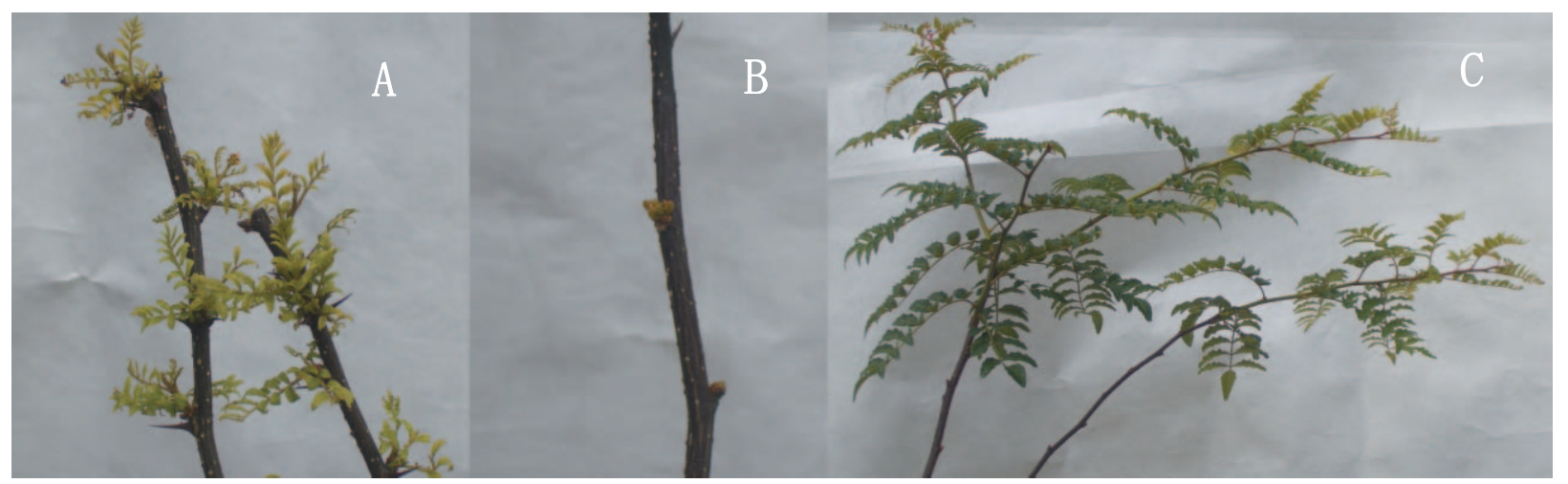

第 6 図 ブドウサンショウ栽培戋場で 9 月 3 日の全摘葉後, NAA200 ppm 区が再発芽し出した時期の秋梢の発生状況（2006.10.3） A : MH6,667 ppm 区 B : NAA200 ppm 区 C : 対照区（水）

ブドウサンショウの収穫は 8 月で終了するが, 病害虫に よる早期落葉に起因する秋梢の発生を防止しなければ翌年 の収量の低下につながる。本試験の結果，病害虫などによ り落葉の始まる前の $8 \sim 9$ 月に NAA200 ppm 水溶液を散布 することによって, 秋梢の発生が防げると思われ，この方
法は生産現場での実用化につながるものと考えられた。

\section{摘 要}

ブドウサンショウの秋季の早期落葉による不時発芽を抑 制する技術を開発する目的で，ブドウサンショウと同じミ 
カン科のウンシュウミカンで実用化されている植物成長調 節剤エチクロゼートと, カンキッ類で用いられていた NAA, MH の 3 剂を用い, 秋梢の発生抑制効果を検討した. 栽培固場で濃度を変えた植物成長調節剂 3 剂を散布し，9 日後に全摘葉して枝を採取して枝挿し法を行らとともに, 試験戋場でも発芽所要日数と発芽率を調査した. その結果, NAA200 ppm 処理での発芽所要日数は約 30 日で, 最も発芽 抑制期間が長く，枝挿し法での発芽枝率は $0 \%$ であった。 た，試験圃場での発芽率も $9 \%$ と有意に低かった。このこ とから, ブドウサンショウの秋梢発生抑制には NAA200 ppm 処理が有効なことがわかった.

\section{引用文献}

Boswell, S. B., B. O. Bergh and R. H. Whitsell. 1976. Control of sprouts on topworked avocado stumps with NAA formulation. HortScience 11: 113-114.

廣瀬和栄. 2003. NAAを使用しない結果母枝の作成法. 農 業技術大系 果樹編 第1巻 カンキッ 追録第 18 号.
1: 10-15. 農文協. 東京.

河瀬憲次・岩垣 功・鈴木邦彦. 1983. カンキッの夏秋枝 抑制について (第 1 報) 各種 $\mathrm{MH}$ 剂の効果. 園学要旨. 昭 58 秋: 540 .

前田隆昭・米本仁巳 - 樋口浩和 - 奥田 均 - 萩原 進 - 谷 ロ正幸. 2007. ブドウサンショウ (Zanthoxylum piperitum (L.) DC. f. inerme Makino）樹の休眠期. 園学研. 6: 565569.

前田隆昭・米本仁巳・村田達郎・奥田 均・萩原 進. 2005. ブドウサンショウの花芽分化期. 園学研. 4: 423-427.

Nauer, E. M. and S. B. Boswell. 1978. NAA sprays suppress sprouting of newly budded citrus nursery trees. HortScience 13: 166-167.

Phillips, R. L. and D. P. H. Tucker. 1974. Chemical inhibition of sprouting of pruned lemon trees. HortScience 9: 199-200.

山下次郎・濱口壽幸. 2002. フィガロン乳剂. 平成 14 年度 常緑果樹関係除草剂・生育調節剂試験成績集録. p. 178181. 財団法人 日本植物調節剂研究協会. 東京. 